\title{
КРИЗИС В КАТАЛОНИИ ИЗМЕНИЛ ПОЛИТИЧЕСКИЙ ОБЛИК ИСПАНИИ
}

\begin{abstract}
Аннотация. Автор анализирует процесс размывания двухпартийной политической системы в Испании, начавшийся в коние 2015 г. Каталонский кризис резко снизил авторитет и влияние в обществе двух старых традиционных партий - Народной и Социалистической рабочей. Упала популярность леворадикальной «Подемос». Ускорилось становление новой силь - партии «Сьюдаданос», вылгравщей парламентские выборы в Каталонии в декабре 2017 г. и сегодня представляющей собой классическую правоцентристскую партию, сумевшую увлечь прагматично разумной политикой разочаровавшихся сторонников правых и левых и значительную часть «молчаливого большинства». Делается вывод о том, что все партии получили временную передышку: до региональных и муниципальных выборов в 2019 г. ещее есть время для анализа произомедмего и выводов на будущее. Одновре́менно перед иентральной властью поставлена задача определения политической конструкции, способной решать реальные проблемы страны.

Ключевые слова: сепаратизм, независимость, политические партии, коалиционное правительство, Женералитет, автономный парламент, Конгресс депутатов, 155 статья Конституции.
\end{abstract}

Острая фаза политического кризиса в Каталонии, начавшегося в 2016 г., рано или поздно пройдёт, она уже и сейчас на спаде, но это вовсе не означает, что сепаратистские устремления в регионе исчезнут. Нет никаких сомнений в том, что новый парламент и новая исполнительная власть будут стремиться выполнить волю своих избирателей - добиваться обретения независимости Каталонии. Национальные политические партии много лет подряд с диаметрально противоположных позиций твердят о необходимости поиска компромиссного решения, основанного на Конституции, которое выбило бы карты из рук сепаратистских сил, но до консенсуса пока, как до луны.

Время работает против них: каталонский кризис резко снизил авторитет и влияние в обществе двух старых традиционных партий - Народной и Социалистической рабочей, сбил спесь с леворадикальной «Подемос» («Мы можем!»). У каждой из них были свои причины для взлёта и падения, и сейчас бесспорной представляется перспектива размывания двухпартийной политической системы в Испании: тот же кризис придал ускорение становлению новой силы - партии «Сьюдаданос» («Граждане»), выигравшей парламентские выборы в Каталонии в декабре 2017 г. Это не какая-то загадочная «третья сила», а классическая, по сути,

(C) Верников Владимир Леонидович - старший научный сотрудник Отдела страновых исследований, руководитель Центра иберийских исследований ИЕ РАН. Адрес: РФ, 125009, Москва, ул. Моховая, д. 11, стр. 3.E-mail: vverkai@gmail.com.

DOI: http://dx.doi.org/10.15211/vestnikieran2201813 
правоцентристская партия, сумевшая увлечь своей прагматично разумной политикой разочаровавшихся сторонников правых и левых и значительную часть «молчаливого большинства».

Процесс размывания хорошо структурированной за 40 постфранкистских лет партийно-политической системы Испании имеет своё зафиксированное начало - парламентские выборы в декабре 2015 г. Тогда ни одна из двух традиционных партий - Социалистическая рабочая и Народная - не получила достаточного количества мандатов для создания правительства большинства, а в стенах Конгресса депутатов - нижней палаты парламента появились две новые партии - леворадикальная «Подемос» («Мы можем!») и правоцентристская «Сьюдаданос» («Граждане»).

\section{Не договорились себе во вред...}

Невозможным оказалось и формирование коалиционного правительства. Правые, с наибольшим числом депутатов имевшие по Конституции право на это, отказались в одиночку от предоставленной им возможности, а социалисты дважды терпели поражение при приведении к присяге своего правительства меньшинства. Досрочные парламентские выборы в июне 2016 г. подтвердили тенденцию к слому двухпартийности: «Подемос» в союзе с Едиными левыми и Народная партия увеличили своё представительство в парламенте, социалисты и «Граждане»- снизили, но сохранили вторую и четвёртую позиции.

Последовавшие затем переговоры о создании Народной партией правительства меньшинства вновь не принесли успеха: социалисты и «Подемос» были против очередного правительства во главе с М. Рахоем. Объективно в создавшейся ситуации вина ложилась на социалистов за их пренебрежение интересами государства, и сами они понимали, что в случае новых выборов, на чём настаивало руководство партии, избиратели могут наказать их ещё большей потерей мест в парламенте. Это стало причиной раскола в партии: социалисты формально возглавили левую оппозицию, но уже тогда было ясно, что из-за непреодолимых разногласий с «Подемос» «левого поворота» в Испании в ближайшие годы ожидать не приходится.

В феврале 2017 г. прошли съезды трёх из четырёх партий, представленных в парламенте, на которых были проанализированы итоги их деятельности за последние годы и намечены тактика и стратегия на будущее. Сейчас, спустя почти 15 месяцев, очевидно, что Народная партия никакой новой экономической политики не выработала, а внутриполитические проблемы, в первую очередь назревавший в Каталонии кризис из-за усиления требований сепаратистских сил о предоставлении независимости, были вообще обойдены вниманием. Эта глухота партии власти вскоре аукнулась ей открытым противостоянием на улицах и площадях Барселоны и других городов региона, введением в действие ст. 155 Конституции, ограничивающей самоуправление, а чуть позже и жестоким поражением на досрочных выборах в местный парламент, где она получила всего 4 ничего не значащих депутатских кресла.

Социалисты провели свой съезд позже, 21 мая, но после двух подряд поражений на парламентских выборах и без отправленного в отставку Исполкома партии глубокий кризис в ИСРП стал с опасением восприниматься не только в ней самой, но и в общественном мнении и в политической элите страны. Если не она, то кто станет лидером оппозиции, способной удержать в узде укрепившую в парламенте свои позиции и склонную к непредсказуемым 
шагам Народную партию? Пока это были лишь риторические вопросы, на которые съезд дал весьма неожиданный ответ: изгнанный с поста генерального секретаря несколько месяцев назад, ошельмованный и третируемый старой партийной гвардией П. Санчес, вопреки всем прогнозам, вновь был избран генсеком.

Тот самый лидер, который в своей партийной программе заявлял о необходимости поиска компромисса с «Подемос», наступавшей социалистам на пятки в парламенте по количеству депутатов и претендовавшей на роль лидера левой оппозиции. И, что казалось многим в партии куда опаснее, с каталонскими националистами - именно это и стало причиной раскола в партии, когда он её недолгое время возглавлял. Не обрадовались такому выбору и в Народной партии, жёстким критиком которой он выступал в парламенте за её экономическую и социальную политику и за вовлечённость в громкие коррупционные скандалы. В «Подемос» был почти траур: её лидер П. Иглесиас понимал, что в нынешней своей ипостаси П. Санчес будет готов договариваться только на своих условиях, ожидать от него уступок не следует.

Об этом он сам достаточно чётко сказал в первом же заявлении после известия о победе: «Мы хотим и создадим новую организацию, исполним выданный нам мандат и сделаем ИСРП по-настоящему левой партией. Моё обещание объединить партию остаётся в силе» ${ }^{1}$ Послание было адресовано партийной массе, менее конформистской в своих политических убеждениях и предпочтениям к компромиссам, чем сам лидер, тем более что его программная платформа вобрала в себя весь негативный опыт европейских социалистических партий последних лет, когда эмоции и демагогические обещания брали верх над реальным состоянием страны и общества.

Очевидно, что победа Санчеса отражает политический кризис европейской представительной демократии - ведь состояние и политика второй по значимости и весу парламентской партии Испании не может не отразиться на всей политической системе страны. Ложная виртуальная реальность и невыполнимые обещания иногда приносят победу на выборах, но всегда ведут к поражению в реальной жизни в политике. По мнению ведущих испанских экспертов, П. Санчесу не удастся в нынешних условиях сформировать в Конгрессе депутатов альтернативное большинство правительству М. Рахоя, пустыми обещаниями выглядят и шансы партии на победу на следующих парламентских выборах.

\section{Социалисты теряют доверие}

Точно так же ему пока не удалось сломать нынешнюю организационную структуру партии, превратить её в подобие «Подемос», когда есть лидер - генеральный секретарь и безликая масса рядовых членов партии, но нет среднего руководящего звена на уровне автономных сообществ и областей. «Проект Санчеса», отвергающий участие в нём всех прежних руководителей партии даже на территориальном уровне, - это идеологический отказ от всего наследства социалистов, свыше 20 лет находившихся у власти и много сделавших для страны, что неизбежно ведёт к углублению внутреннего кризиса. Предлагаемая им модель пар-

\footnotetext{
${ }^{1}$ El Pais, 22.05.2017.
} 
тии вряд ли способна привлечь новых сторонников на следующих парламентских выборах и привести социалистов к власти.

Первый сигнал неблагополучия они получили на тех самых досрочных выборах в Каталонии, где завоевали постыдно малое количество депутатских мест в автономном парламенте. Оценив политическую конъюнктуру в стране, социалисты, задумываясь о своём электоральном будущем в масштабах Испании, забыли об обещанном поиске компромисса с националистами и выступили вместе с народниками резко против сепаратистских планов коррумпированной каталонской элиты, приветствовали введение в действие уже упоминавшейся ст. 155 Конституции. Но в ходе самого каталонского кризиса не раз проявляли нерешительность, тактически подыгрывая и тем, и другим, что и сказалось на результатах выборов - в массе своей каталонцы отказали им в доверии на власть и отдали предпочтение партии «Сьюдаданос», ставшей формальным победителем без абсолютного большинства мандатов.

Съезд «Сьюдаданос» в том же феврале 2017 г. прошёл почти не замеченным политологическим сообществом и конкурентами из других партий. От него не ждали каких-либо прорывных национальных экономических программ или политических инициатив - партия успешно развивается, но пока слишком мала и мало узнаваема в национальном масштабе. Да, она стала де-факто национальной - четвёртой по численности мандатов в Конгрессе депутатов, хотя ещё недавно позиционировала себя как каталонская. Взвешенные инициативы и способность к компромиссам в ходе переговоров сначала с социалистами, а затем и с народниками о создании коалиционных правительств подняли личный рейтинг А. Риверы как человека с государственным мышлением и авторитет самой партии.

Дальнейшие действия партии в парламенте, в том числе при обсуждении бюджета страны на 2017 г., а затем и бескомпромиссная позиция по отношению к сепаратистским тенденциям в Каталонии, принесли ей первый большой и неожиданный для многих успех на досрочных выборах, о чём мы уже упоминали выше. За них отдали свои голоса, как утверждают социологи, не только давние сторонники, стоявшие у истоков рождения партии, но и члены партии неудачников - народников и даже социалистов, которые тем самым высказали своё неприятие политики и неуклюжих действий правительства. Тем не менее А. Ривера категорически отказался от намерения формировать правительство, ссылаясь на «арифметику» в парламенте.

М. Рахой все последние месяцы настойчиво подталкивал его к противоестественному временному союзу с «Подемос», 8 депутатов которой в сумме с 36 их собственными дадут искомое большинство, чтобы «взять на себя ответственность за будущее региона и в интересах всего государства» 1 . Но это пустые хлопоты - лидер «Граждан» смотрит далеко вперёд и не станет рисковать авторитетом партии и собственным в преддверии более важных выборов. Впрочем, и другой его виртуальный партнёр - каталонские социалисты вряд ли готовы на такой почти самоубийственный пируэт - они не пошли на союз с «Подемос» в Кортесах, лишившись возможности создать первый и действительно левый правительственный кабинет в 2016 г.

${ }^{1}$ El Pais, 03.01.2018. 


\section{Правые борются между собой за место под солнцем}

На съезде А. Ривера обозначил перспективу - выиграть следующие парламентские выборы. Тогда многие наблюдатели, и автор этой статьи в том числе, посчитали это нереальной мечтой - партии не хватает массовости, она не внедрена в местные и региональные органы власти, а правый центр, к которому себя относит, занят Народной партией. Последние месяцы внесли коррективы: «Сьюдаданос» уже являются серьёзным политическим игроком, о чём говорит её успех в Каталонии и работа в национальном парламенте. По данным социологов, в случае досрочных выборов в региональное правительство провинции Мадрид из-за его ухода в отставку в результате коррупционного скандала, «Граждане» стали бы победителями с большим отрывом от Народной партии.

М. Рахой, политик опытный и ловкий, почувствовал угрозу для своей партии и заблаговременно начал игру с набирающим силу соперником. Пробным шаром в заведомо проигрышной для А. Риверы партии стало, как мы уже знаем, предложение сформировать правительство Каталонии. Затем последовали дискредитирующие «Сьюдаданос» наскоки народников в Конгрессе депутатов при обсуждении бюджета на 2018 г. и обвинения в лояльных СМИ в недоговороспособности, лживости и политической близорукости лидера партии.

По мнению обозревателей, это отвлекающий манёвр: «Виртуозная борьба между ними в разгаре, но она не что иное, как состязание в том, чьё предложение более консервативно, т.к. речь идёт о завоевании правого центра в политической жизни. Обе партии роднит повестка дня, темы дебатов и стратегические соглашения между правительством и партией-конкурентом при голосовании в парламенте» ${ }^{1}$. В левом спектре политической системы и в региональных партиях, представленных в парламенте, с тревогой следят за намечающимся сговором обеих правых партий и их откровенным стремлением разделить электоральное поле к взаимной выгоде.

При полной разобщённости левых партий им остаётся быть лишь сторонними наблюдателями. «Подемос» не только окончательно рассорилась с социалистами, но и погрязла во внутренних сварах и борьбе за лидерство ${ }^{2}$. Как можно доверять политической партии, в которой два её основателя планируют заговор, чтобы избавиться от признанного лидера, а когда тайное стало явным, публично раскаялись и получили от него же отпущение грехов «в интересах единства партии». Из ранее созданных в регионах избирательных блоков с мелкими левыми группами и объединениями мало что осталось, они покинули партию, разочаровавшись в её политике и каудильистских настроениях лидеров. Полное поражение партии на досрочных выборах в Каталонии стало следствием двурушнической позиции в вопросе об отделении и создании независимого государства, и этот ярлык презрения и отсутствия собственного лица не су-лит ей никаких перспектив на национальном уровне.

\footnotetext{
${ }^{1}$ El Pais, 03.04.2018.

${ }^{2}$ Там же, 20.04.2018.
} 


\section{Выводы}

Так политический кризис в Каталонии определил на конец апреля место и роль ведущих политических партий Испании. Неожиданно для самих себя они получили временную передышку: до региональных и муниципальных выборов в 2019 г. ещё есть время для анализа произошедшего и выводов на будущее. Но и центральной власти, проявившей в этом конфликте и силу, и слабость одновре́менно, пора определиться, какой она видит политическую конструкцию, способную решать реальные проблемы страны. Слов по этому поводу сказано много, нужны конкретные реформы административного и экономического механизма управления автономиями и регионами, в которые будут вовлечены все политические силы Испании.

\section{Список литературы}

Consecuencias economicas de una hipotetica independencia de Cataluna. URL: http://www.exteriores. gob.es/Portal/es/Sala de Prensa/El ministerio informa/Documento.

Inigo Errejon. Tribuna. Cooperar para desbloquear Espana. El Pais, 03.04.2018.

Pere Rios. CIS/Cataluna. La opcion autonomista se impone por primera vez desde el inicio del «process». El Pais, 24.02.2018.

Верников В.Л. Кризис политической системы или вызов времени? Современная Европа, №1, 2017.

Верников В.Л. Каталония - «замороженный» конфликт. Современная Европа, №2, 2018.

Верников В. Каталония остаётся опасным очагом сепаратизма. Аналитическая записка №2(98), 2018. Доступ: http://www.instituteofeurope.ru/images/uploads/analitika/an98.pdf.

Верников В. У кризиса в Каталонии есть начало, но не видно конца. Аналитическая записка №11 (107), 2018. Доступ: http://www.instituteofeurope.ru/images/uploads/analitika/2018/an 107.pdf.

\section{References}

Jose Marcos. Iglesias zanja con un acuerdo entre Errejon y Espinar la crisis en Podemos. URL:https://politica.elpais.com/politica/2018/04/19/actualidad/1524152643_193295.html.

Inigo Dominguez. PP y Ciudadanos agitan el miedo al "process" en Navarra, Valencia y Baleares. URL: https://politica.elpais.com/2018/04/29/ actualidad/ 1524997206_930668.html.

Vernikov V. Katalonia - «zamoroghenniy» conflict. Sovremennaya Evropa, №2, 2018

\section{The Catalonian Crisis has changed the political Image of Spain}

Author. Vernikov V. - Head of Center for Iberic studies, Institute of Europe, Russia Academy of Sciences. Address: 11-3, Mokhovaya str., Moscow, Russia, 125009. E-mail: vverkai@gmail.com. 


\begin{abstract}
The author analyses the erosion of the two-party system in Spain since the end of 2015. The Catalonian crisis has drastically diminished the reputation and influence of the two traditional parties - the People's and the Spanish Socialist Workers'. The popularity of the radical left «Podemos» party has also fallen. The new political force - the «Cuidadanos» party that had won the parliamentary elections in Catalonia in December 2017, now is a classic party of the center right. It managed to attract the disillusioned supporters from the right, as well as from the left, and from the «silent majority» by pragmatic sensible policy. The conclusion is that all the parties have got a temporary break: there is still time left before regional and municipal elections in 2019 to analyse the immediate past and draw lessons for the future. At the same time the authorities in Madrid are to solve the issue of constructing a viable political mechanism able to deal with the real problems of the country.
\end{abstract}

Key words: Spain, Catalonia, separatism, independence, political parties, coalition government, autonomous parliament, Generalitat, the Congress of Deputies, Constituttion of Spain article 155.

DOI: http://dx.doi.org/10.15211/vestnikieran2201813 